University of Nebraska - Lincoln

DigitalCommons@University of Nebraska - Lincoln

\title{
Land use effects on pesticides in sediments of prairie pothole wetlands in North and South Dakota
}

\author{
Scott T. McMurry \\ Oklahoma State University, scott.mcmurry@okstate.edu \\ Jason B. Belden \\ Oklahoma State University \\ Loren M. Smith \\ Oklahoma State University \\ Shane A. Morrison \\ Oklahoma State University \\ Dale W. Daniel \\ Oklahoma State University
}

See next page for additional authors

Follow this and additional works at: https://digitalcommons.unl.edu/usgsnpwrc

McMurry, Scott T.; Belden, Jason B.; Smith, Loren M.; Morrison, Shane A.; Daniel, Dale W.; Euliss, Betty R.; Euliss, Ned H. Jr.; Kensinger, Bart J.; and Tangen, Brian A., "Land use effects on pesticides in sediments of prairie pothole wetlands in North and South Dakota" (2016). USGS Northern Prairie Wildlife Research Center. 305.

https://digitalcommons.unl.edu/usgsnpwrc/305

This Article is brought to you for free and open access by the US Geological Survey at DigitalCommons@University of Nebraska - Lincoln. It has been accepted for inclusion in USGS Northern Prairie Wildlife Research Center by an authorized administrator of DigitalCommons@University of Nebraska - Lincoln. 


\section{Authors}

Scott T. McMurry, Jason B. Belden, Loren M. Smith, Shane A. Morrison, Dale W. Daniel, Betty R. Euliss, Ned H. Euliss Jr., Bart J. Kensinger, and Brian A. Tangen 


\title{
Land use effects on pesticides in sediments of prairie pothole wetlands in North and South Dakota
}

\author{
Scott T. McMurry ${ }^{a}$, Jason B. Belden ${ }^{a}$, Loren M. Smith ${ }^{a}$, Shane A. Morrison ${ }^{a}$, Dale W. Daniel ${ }^{a}$, Betty R. Euliss ${ }^{\text {b, } 1}$,
} Ned H. Euliss Jr. ${ }^{b, 1}$, Bart J. Kensinger ${ }^{a}$, Brian A. Tangen ${ }^{b}$

a Department of Integrative Biology, Oklahoma State University, Stillwater, OK 74078, United States

b USGS Northern Prairie Wildlife Research Center, Jamestown, ND 58401, United States

\section{H I G H L I G H T S}

- Herbicides and fungicides, but not insecticides, were found in wetland sediments.

- Upland land use had minimal effect on overall presence of some pesticides.

- Conservation Reserve Program uplands protected wetlands from glyphosate input.
G R A P H I C A L A B S T R A C T
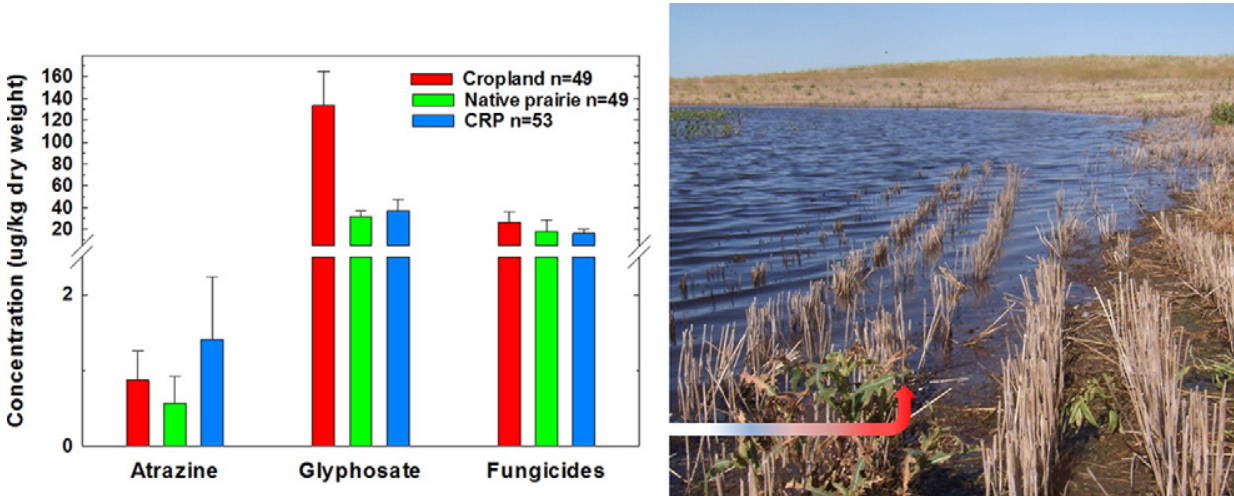

A B S T R A C T

Prairie potholes are the dominant wetland type in the intensively cultivated northern Great Plains of North America, and thus have the potential to receive pesticide runoff and drift. We examined the presence of pesticides in sediments of 151 wetlands split among the three dominant land use types, Conservation Reserve Program (CRP), cropland, and native prairie, in North and South Dakota in 2011. Herbicides (glyphosate and atrazine) and fungicides were detected regularly, with no insecticide detections. Glyphosate was the most detected pesticide, occurring in $61 \%$ of all wetlands, with atrazine in only $8 \%$ of wetlands. Pyraclostrobin was one of five fungicides detected, but the only one of significance, being detected in $31 \%$ of wetlands. Glyphosate was the only pesticide that differed by land use, with concentrations in cropland over four-times that in either native prairie or CRP, which were equal in concentration and frequency of detection. Despite examining several landscape variables, such as wetland proximity to specific crop types, watershed size, and others, land use was the best variable explaining pesticide concentrations in potholes. CRP ameliorated glyphosate in wetlands at concentrations comparable to native prairie and thereby provides another ecosystem service from this expansive program.

(c) 2016 Elsevier B.V. All rights reserved.
E-mail address: scott.mcmurry@okstate.edu (S.T. McMurry).

1 Retired.

\section{Introduction}

Over 15 million ha of grassland in the Great Plains have been converted to support production agriculture (Samson and Knopf, 1994; Smith, 2003), which frequently have significant fertilizer and pesticide 
input. Pesticides have been reported to commonly occur in streams and rivers throughout agricultural intensive regions in the United States (Gilliom, 2007). In addition, cultivation increases the potential of soil erosion, which may result in increased transport of pesticides. Thus, depressional wetlands, which are common to the intensively cultivated regions of the Great Plains (Smith et al., 2008), are likely to receive agricultural contaminants via drift, overspray and overland flow in water or sediment (Belden et al., 2012).

To protect fragile uplands, wetlands, and their services throughout the United States, federal funds have been put into various programs administered through the United States Department of Agriculture (USDA), such as the Wetland Reserve Program (WRP) and the Conservation Reserve Program (CRP). The CRP is the largest federal conservation program in the United States; designed to retire private lands from agricultural production as both a commodity management strategy and as a means to increase environmental benefits provided to people (USDA, 2013). Indeed, the recreational value alone provided by increased wildlife habitat on CRP acres has been estimated to be worth about $\$ 963$ million/year (Sullivan et al., 2004; Wu and Weber, 2012). Ecosystem services potentially improved by implementing conservation programs and practices include improving habitat, water quality, flood water storage, groundwater recharge, nutrient cycling, and reducing input of sediment and chemicals/nutrients (Euliss et al., 2011; Smith et al., 2011). Recent studies have demonstrated the ability of CRP to reduce sediment and pesticide concentrations in depressional wetlands throughout the Southern Great Plains (Belden et al., 2012; Daniel et al., 2014). Currently, CRP enrollment cap is scheduled to drop from nearly 13 million ha to around 9.7 million ha by 2018 , as outlined by the 2014 Farm Bill (Stubbs, 2013), which may have implications for ecosystem service provisioning in regions with high densities of CRP lands.

The Prairie Pothole Region (PPR) extends from the north central United States to southern Canada, and represents the northern extent of the Great Plains. Covering approximately $900,000 \mathrm{~km}^{2}$, the PPR constitutes a major physiographic region, with CRP on over 2 million ha. Originally composed primarily of short to tall grass prairie with interspersed wetlands (prairie potholes) and river systems, the PPR has experienced significant changes over the past 200 years, as agriculture has become the dominant land use practice in the region, which along with widespread drainage of wetlands has resulted in significant loss of wetlands and their associated biodiversity and ecosystem services (Dahl, 2014; Johnston, 2013). Regardless, prairie pothole wetlands are still a major feature of the region and characterized as depressional wetlands of glacial origin that can range from a few hectares to tens of hectares in size. These wetlands are subject to continued pressure from agriculture, including sedimentation, altered hydrology and subsequent effects on biota and abiotic processes, and fertilizer and pesticide input originating from upland cultivation that can extend to the edge of the wetland (Euliss et al., 2011).

Previous work has documented pesticide contamination in depressional wetlands (playas) ranging from the Southern High Plains through the Rainwater Basin of Nebraska (Belden et al., 2012). That study demonstrated the ability of two conservation programs (CRP and WRP) to mitigate pesticide contamination in wetlands. Given the extensive use of CRP in the intensely cultivated PPR, the main goal of this study was to examine if the presence of CRP in the upland influenced pesticide contamination in sediments relative to the other dominant land use types; cropland and native prairie. Further, we evaluated a variety of other landscape level factors (e.g., crop type, distance to fields, etc.) as predictors of pesticides in sediments. Pesticide contamination has been reported in wetland water in the northern portion of the Prairie Pothole region (Donald et al., 1999; Messing et al., 2011). However, these studies did not measure several important current-use pesticides, focused on water, and did not differentiate contamination based on land-use around wetlands. Our study was conducted in North and South Dakota, where we sampled wetlands from the three land use types and screened for commonly used pesticides. Our sampling regime focused on sediments as the primary sink for many pesticides. Dissipation half-lives in sediment are also typically longer than water, increasing our chances of detecting contamination. We report the presence of pesticides and their concentrations and frequency of occurrence relative to land use. In addition, we discuss the relationship between pesticide endpoints and surrounding crop types.

\section{Materials and methods}

\section{1 materials}

Neat standards ( $>98 \%$ purity) of all analytes were purchased from Sigma-Aldrich (St. Louis, MO). All solvents and reagents were pesticide or GC/MS grade.

\section{2 site selection}

A total of 151 wetlands ( 49 cropland, 49 native prairie, and 53 restored) were sampled late June and early July 2011. This sampling period was likely effective for pesticides applied at planting and early life stages as most field crops are planted in May or Early June in the region (http://www.rma.usda.gov/fields/mt_rso/2015/final/). However, it may have missed later season applications of some pesticides such as fungicides and insecticides applied at the tassle stage in corn. Wetlands were located within the Glaciated Plains and Missouri Coteau portions of the PPR of North and South Dakota (Fig. 1; Gleason et al., 2011). This region receives an average range of $5-10 \mathrm{~cm}$ of precipitation per month from May to July (http://www.usclimatedata.com). Native prairie and cropland wetlands were classified according to the dominant land use type in their immediate upland watershed. For cropland wetlands, crop type in the immediate watershed was determined during sampling. The most common crop type was soybeans (34\%) followed by corn (32\%) and wheat (18\%). Less common crop types included canola and millet. For this study, restored wetlands were those historically embedded in active cropland but since removed from cultivation. Some restored wetlands had hydrological restoration work implemented within basin (drain plugging, pit filling), but all wetlands had immediate watersheds replanted to grass cover through the CRP. Sampled wetlands were also classified by water regime (temporary, seasonal, or semi-permanent) following Cowardin et al. (1979) and provided by USGS Northern Prairie Wildlife Research Center. Mean $( \pm$ SD) percent organic matter in sediments was similar among land use types, ranging from $0.07 \pm 0.02$ in CRP wetlands to $0.08 \pm 0.03$ and $0.11 \pm 0.07$ in cropland and native grassland wetlands, respectively (loss on ignition method).

\subsection{Sediment sampling}

Wetland sediments were sampled from the wetland center and then five equidistant points within the wetland, surrounding the center, ranging from about 10 to $30 \mathrm{~m}$ from shore depending on wetland size and configuration. Equal amounts of sediment $(80 \mathrm{mls})$ were collected from the top $5 \mathrm{~cm}$ at each sample location and combined in a single $500 \mathrm{~mL}$ sample jar for each wetland (Shelton and Capel, 1995). The top $5 \mathrm{~cm}$ was sampled to account for any mixing and because many organisms move throughout the top few centimeters of sediment. Prior to sample analysis, all sediment samples were homogenized and subsampled for the required testing procedure.

\subsection{Pesticide extraction and analysis}

Eighteen pesticides were chosen as analytes based on usage data for the region obtained from the US Department of Agriculture National Agricultural Statistics Statistic Service (http://www.nass.usda. gov/Surveys/Guide_to_NASS_Surveys/Chemical_Use/), feasibility for 


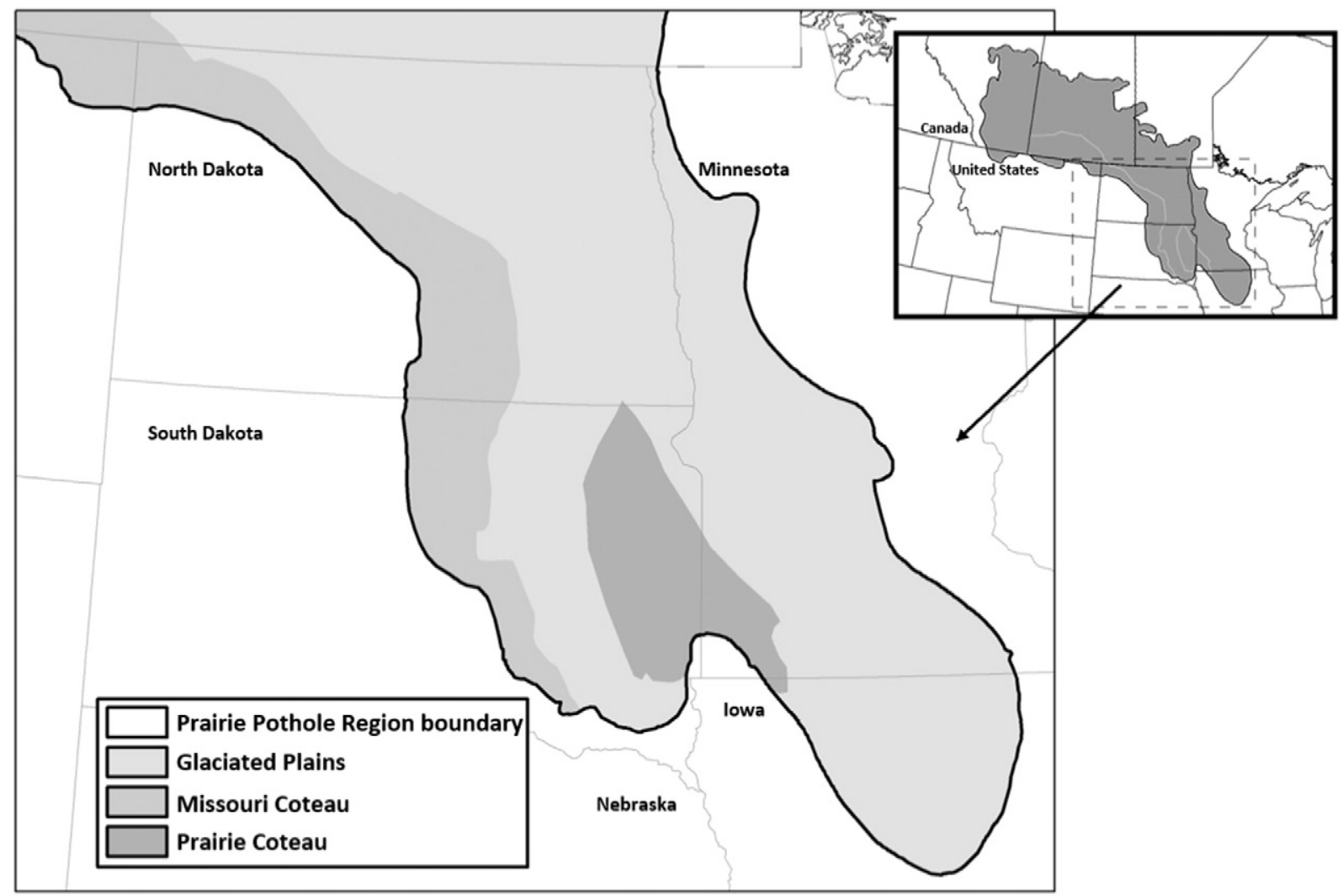

Fig. 1. Map of the Prairie Pothole Region extending across parts of Canada and the United States, including our study area in North and South Dakota.

analysis using the available techniques, and potential toxicity. Seventeen of the selected analytes are extractable with organic solvent and can be directly analyzed using gas chromatography coupled with mass spectrometry allowing a single measurement technique (Table 1 ). In addition glyphosate was measured using an immunoassay technique.

Sediment dispersion followed Morrison et al. (2013). Briefly, ceramic mortars were loaded with $1.5 \mathrm{~g}$ homogenized sediment with 750-mg diatomaceous earth, 900-mg Florisil, and 50-mg primary secondary amine-bounded silica ground together until homogenized. Extraction was conducted by passing $15-\mathrm{mL}$ of hexane:ethyl ether $(1: 2, \mathrm{v} / \mathrm{v})$ through an extraction column assembled from the bottom up with 500-mg activated silica gel, 1000-mg sodium sulfate, and finally the dispersed sediment, collecting the effluent. Collected effluents were stored at $-20{ }^{\circ} \mathrm{C}$ until evaporated under a stream of nitrogen to a final volume of $500 \mu \mathrm{L}$ until analysis.

Analysis of chemical residues was performed using gas chromatography/mass spectrometry (GC/MS; Agilent 5975c, Santa Clara, CA, USA) using electron ionization ( $70 \mathrm{eV})$. The GC inlet temperature was $260{ }^{\circ} \mathrm{C}$ and the oven was programed to start and hold $120{ }^{\circ} \mathrm{C}$ for $1.0 \mathrm{~min}$ ramp $8{ }^{\circ} \mathrm{C} / \mathrm{min}$ to $300^{\circ} \mathrm{C}$ and hold for $4 \mathrm{~min}$. Separation was achieved using a $30 \mathrm{~m} \times 250 \mu \mathrm{m} \times 0.25 \mu \mathrm{m}$ HP-5 capillary column (Agilent). Three-ion selected ion monitoring (SIM) was utilized for

Table 1

Quantitation limits, identification parameters, and mean $( \pm S D)$ extraction efficiencies.

\begin{tabular}{|c|c|c|c|c|}
\hline Pesticide & Retention time (min) & Quantitation limit $(\mu \mathrm{g} / \mathrm{kg})$ & Quantification ion:qualification ions $(m / z)$ & Extraction efficiency, mean $( \pm S D)$ \\
\hline \multicolumn{5}{|l|}{ Fungicides } \\
\hline Azoxystrobin & 21.74 & 10 & $344: 345,403$ & $109(41)$ \\
\hline chlorothalonil & 8.99 & 10 & $266: 264,229$ & $72(20)$ \\
\hline Propiconazole & $14.9 / 15.05$ & 10 & $259: 261,173$ & $159(27)$ \\
\hline Pyraclostrobin & 20.58 & 10 & $164: 132,325$ & $184(22)$ \\
\hline Trifloxystrobin & 15.13 & 10 & $222: 206,116$ & $110(9)$ \\
\hline \multicolumn{5}{|l|}{ Herbicides } \\
\hline Acetochlor & 9.82 & 10 & $223: 162,146$ & $92(11)$ \\
\hline Atrazine & 8.11 & 10 & $215: 200,173$ & $96(9)$ \\
\hline Desethyl atrazine & 6.98 & 10 & $187: 174,172$ & $80(9)$ \\
\hline Trifluralin & 7.25 & 2 & $306: 264,290$ & $60(19)$ \\
\hline \multicolumn{5}{|l|}{ Insecticides } \\
\hline Bifenthrin & 16.27 & 2 & $181: 166,165$ & $108(14)$ \\
\hline Chlorpyrifos & 11.04 & 10 & $314: 316,197$ & $102(6)$ \\
\hline Cyfluthrin & 19.26/19.31 & 10 & $227: 206,226$ & $126(20)$ \\
\hline Esfenvalerate & 20.76 & 10 & $225: 167,125$ & $100(13)$ \\
\hline Lambda cyhalothrin & 17.49 & 10 & 208:197,181 & $103(25)$ \\
\hline Methyl parathion & 9.86 & 10 & $263: 125,109$ & $95(43)$ \\
\hline \multicolumn{5}{|l|}{ Surrogate } \\
\hline Atrazine D5 & 8.07 & 10 & $220: 205,178$ & $83(11)$ \\
\hline Dibutyl chlorendate & 17.01 & 10 & $390: 373,389$ & $89(9)$ \\
\hline
\end{tabular}


calibration (Table 1). All three SIM ions had to be present with the proper ratios (30\%) for any analyte response to be reported. Deuterated PAHs were used as internal standards. Continuing calibration was confirmed $( \pm 15 \%)$ at a minimum of every 10 samples. Quantitation limits (QL) were set at the lowest concentration where all three ions were reliably measurable in samples and were higher than the method detection limit as calculated by measuring low-level laboratory spikes of clean reference sediment obtained from a wetland in Nebraska that had been previously determined to not to be contaminated with pesticides of interest (Table 1).

Laboratory matrix spikes $(n=8)$ and blanks $(n=2)$ consisted of the clean reference sediment and were concurrently analyzed with unknown samples. Matrix spikes and matrix duplicates were performed at $5 \%$ frequency. Surrogate (atrazine D-5 and dibutyl chlorendate) was added to each sample prior to homogenization. All matrix spikes and surrogates were fortified into the sediment using an acetone solvent carrier prior to extraction.

Extraction of sediment-bound glyphosate was achieved by weighing out $5.0 \mathrm{~g}$ of sediment into $15 \mathrm{~mL}$ plastic centrifuge tubes and adding $12.5 \mathrm{~mL}$ of $1 \mathrm{M} \mathrm{NaOH}$. Extraction tubes were placed on auto-rotators for $30 \mathrm{~min}$ followed by a 4 min centrifuge at $2.5 \mathrm{~g}$ to ensure sedimentation. Each sample was filtered by passing $4.0 \mathrm{~mL}$ sample extract through a Pasteur pipette packed from bottom to top with glass wool and $0.5 \mathrm{~g}$ $\mathrm{Na}_{2} \mathrm{SO}_{4}$. Filtered extracts were diluted 1:100 with deionized water. Extracts were analyzed by enzyme linked immunosorbent assay (ELISA). Preparation of reagents and standards and subsequent analysis was conducted following instructions provided with the Abraxis Glyphosate Plate Kit (Warminester, PA). Standards, controls, and samples were randomly dispersed throughout the plates. Calibration curves, negative controls (blank extraction matrix), and positive controls (total spiked matrix extractions, $n=13$ ) were included on each plate analyzed at a minimum $(n=5)$. Extraction of sediment-bound glyphosate using the Abraxis Glyphosate Plate Kit has a quantitation limit of $20 \mu \mathrm{g} / \mathrm{kg}$.

\subsection{Quality control}

For the semi-volatile pesticide analysis, concentrations in all laboratory blanks were below quantitation limits ( $n=3$; Table 1 ). Mean extraction efficiencies $( \pm S D)$ were calculated by dividing the recovered analyte concentration by the fortified concentration and taking the mean of all replicates (Table 1 ). Recovery generally ranged from 70 to $130 \%$ of expected with the exception of trifluralin (60\%) and two fungicides, propiconazole and pyraclostrobin (159 and 184\%, respectively). Given the absence of pesticide detection in blanks, high recoveries for propiconazole and pyraclostrobin were not related to contamination issues, but rather matrix enhancements of recoveries as has been previously reported for fungicides in other matrices (Battaglin et al., 2011). Previous studies in the same laboratory that focused on fungicide analysis had better recoveries using a shorter column and higher GC temperatures (Morrison et al., 2013). Although the reported values may be biased slightly high for these two compounds, they should be high across land use categories allowing comparisons to be made. Surrogate recoveries from individual samples were $99 \pm 21 \%$ (mean \pm SD) for atrazine-D5 and $87 \pm 19 \%$ for dibutyl chlorendate matching recoveries found in extraction efficiency studies suggesting that extraction efficiencies are an adequate assessment of recoveries in all samples. For the glyphosate analysis, concentrations in all laboratory blanks were below quantitation limits $(\mathrm{n}=5 ;<20 \mu \mathrm{g} / \mathrm{kg}$ ). Spiked extracts were with $80 \pm 19 \%$ of expected.

\subsection{Statistical analysis}

A Kruskal-Wallis test was used to test for differences in the number of pesticide occurrences among wetlands in cropland, native prairie, and CRP. We also tallied the number of pothole wetlands in each landuse type that contained at least one pesticide (of the seven detected pesticides; atrazine, glyphosate, and the five fungicides) and compared the proportion of each using a chi-squared test. In addition, we used the Kruskal-Wallis test to compare concentrations $(\mu \mathrm{g} / \mathrm{kg})$ of the seven detected pesticides among potholes in cropland, native prairie, and CRP, followed by a protected Tukey-Kramer test. We further explored the influence of other landscape level factors on pesticide concentrations in wetlands. First, we used linear regression and $\mathrm{R}^{2}$ values to predict concentration of the seven detected pesticides using the minimum distance $(\mathrm{m})$ between the wetland and specific crop types (determined from NASS data and distances computed in GIS framework). For these analyses we also used logistic regression to predict pesticide presence/absence of the seven pesticides to improve the signal. Next we added the concentrations of the five fungicides together to increase the power of our analysis. Further, we treated alfalfa as its own crop category, clustered the cereals (barley, durum, oats, spring wheat, and winter wheat), and clustered corn and soybeans to further increase our power of detection. These groupings were based on the fact that they constituted a large proportion of the crop types recorded for the area and our best judgment of their similar management. We again used linear regression and $\mathrm{R}^{2}$ values to predict the concentration of atrazine, glyphosate, and the fungicides by the minimum distance of any of our crop categories: alfalfa, cereals, or corn/soy. Further, we used the total area of each crop type (ha) for the nearest 15 crop fields to the watershed, rather than minimum distance to each crop type. Lastly, we examined the relationship between watershed size (ha) and pesticide concentrations (linear regression) and detections (logistic regression). This analysis addressed whether or not larger watersheds are more at risk for contamination. We attained watershed sizes by two methods. Detailed survey data collected by NPWRC were available for 83 of the 151 study wetlands. For the remaining 68 wetlands, we estimated the watershed size (Gleason and Tangen, 2008) by the formula Watershed Area (ha) $2.24 *$ Pothole Area (ha) ${ }^{0.4647}$. We first performed an analysis using data from only the 83 surveyed wetlands. We then repeated our analysis using the full data set (i.e., all 151 wetlands) to increase the power. With linear regressions and $\mathrm{R}^{2}$ values we examined the relationship between both watershed area (land area that drains into the pothole) and water catchment area (which includes watershed area plus the area of the pothole itself).

\section{Results}

Seven of the 18 pesticides tested were detected at least once in a total of 151 sediment samples (Table 2). Average number of pesticides per wetland did not differ among land-use types $\left(X^{2}=4.824, \mathrm{df}=2\right.$, P-value $=0.089$ ), although there was a trend towards greater occurrence of pesticides in cropland wetlands (Fig. 2). We also did not detect land use differences in the proportion of wetlands contaminated with at least one pesticide, as about $70-80 \%$ of wetlands were contaminated, regardless of land use ( $X^{2}=3.0553, \mathrm{df}=2$, P-value $=0.217$; Fig. 3 ).

Only glyphosate, atrazine, and pyraclostrobin and other fungicides were detected often enough to warrant further analysis. Glyphosate was the most commonly detected compound, being found in $61 \%$ of all samples (Table 2). Differences among land use types were evident for glyphosate, which was detected in $76 \%$ of all crop wetlands, but only 53-55\% of CRP and native grassland wetlands (KruskalWallis $\chi^{2}=20.21$, df $=2, \mathrm{P}<0.01$; Table 2). In addition, glyphosate concentrations in cropland wetlands were about 4 times greater (Tukey-Kramer post-hoc; $\mathrm{P}<0.01$ ) than in either native prairie or CRP, which did not differ from one another ( $\mathrm{P}=0.98$; Fig. 4).

Pyraclostrobin was the second most frequently detected pesticide, with detections in 28-33\% of all wetland sediments (Table 2). Unlike glyphosate pyraclostrobin concentrations were similar among land use types, as reflected by overall fungicide concentrations (Kruskal-Wallis $\mathrm{X}^{2}=0.387, \mathrm{df}=2, \mathrm{P}=0.82$; Fig. 4). The maximum pyraclostrobin value $(410 \mu \mathrm{g} / \mathrm{kg}$ ) was observed in a cropland and was 4 times that of the maximum values for either CRP or native 
Table 2

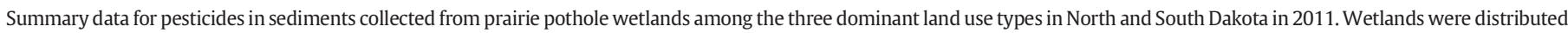
among the three dominant land use types: active cropland, native prairie, and Conservation Reserve Program (CRP) land.

\begin{tabular}{|c|c|c|c|c|c|c|c|}
\hline & \multicolumn{2}{|c|}{ Number of samples } & \multirow[t]{2}{*}{$\mathrm{QL}^{\mathrm{a}}$} & \multirow[t]{2}{*}{ Freq. $>$ QL, \% } & \multirow[t]{2}{*}{ Max. value, $\mu \mathrm{g} / \mathrm{kg}$} & \multirow[t]{2}{*}{ Median > QL, $\mu \mathrm{g} / \mathrm{kg}$} & \multirow{2}{*}{$\begin{array}{l}\text { 90th percentile } \\
\text { all samples }(\mu \mathrm{g} / \mathrm{kg}) \\
90\end{array}$} \\
\hline & Total & $>Q L$ & & & & & \\
\hline \multicolumn{8}{|l|}{ Glyphosate } \\
\hline Cropland & 49 & 37 & & 76 & 1200 & 90 & 370 \\
\hline CRP & 53 & 28 & & 53 & 530 & 41 & 66 \\
\hline Native prairie & 49 & 27 & & 55 & 180 & 50 & 72 \\
\hline \multicolumn{8}{|l|}{ Atrazine } \\
\hline Cropland & 49 & 5 & 3 & 10 & 12 & 8.3 & $<\mathrm{QL}$ \\
\hline CRP & 53 & 4 & 3 & 7.5 & 38 & 15 & $<\mathrm{QL}$ \\
\hline Native prairie & 49 & 3 & 3 & 6.1 & 15 & 6.6 & $<\mathrm{QL}$ \\
\hline \multicolumn{8}{|l|}{ Pyraclostrobin } \\
\hline Cropland & 49 & 16 & 15 & 33 & 410 & 25 & 43 \\
\hline CRP & 53 & 15 & 15 & 28 & 120 & 44 & 57 \\
\hline Native prairie & 49 & 15 & 15 & 31 & 120 & 33 & 74 \\
\hline \multicolumn{8}{|c|}{ Sum fungicides ${ }^{\mathrm{b}}$} \\
\hline CRP & 53 & 18 & $3-15$ & 34 & 120 & 41 & 60 \\
\hline Native prairie & 49 & 16 & $3-15$ & 33 & 120 & 34 & 79 \\
\hline
\end{tabular}

a $\mathrm{QL}=$ quantitation limit.

b Includes all fungicides detected, including pyraclostrobin.

prairie, but overall differences among land use types were negligible (Table 2). Four additional fungicides (chlorothalonil, propiconazole, trifloxystrobin, and azoxystrobin) were detected in addition to pyraclostrobin, but only in 15 of 151 samples. The highest was a chlorothalonil concentration of $210 \mu \mathrm{g} / \mathrm{kg}$ and a propiconazole concentration of $110 \mu \mathrm{g} / \mathrm{kg}$, both in cropland wetlands. The remaining $13 \mathrm{sam}-$ ples were all below $50 \mu \mathrm{g} / \mathrm{kg}$ and were detected in all land use types.

Atrazine was detected in 12 of 151 samples at relatively low concentrations (average $0.86-1.4 \mu \mathrm{g} / \mathrm{kg}$ ). The maximum atrazine concentration was $38 \mu \mathrm{g} / \mathrm{kg}$ from a CRP wetland, but we detected no land use effect (Kruskal-Wallis $\chi^{2}=0.519, \mathrm{df}=2, \mathrm{P}=0.77$; Fig. 4).

Linear regression analyses of the influence of landscape factors (minimum distance to crop fields, total area of crop fields, watershed area, and catchment area) on wetland pesticide concentrations yielded no relationships that explained $>10 \%$ of the variation $\left(R^{2}<0.10\right.$ for all tests). Further, using logistic regression did not improve the relationship between landscape factors and pesticide presence or absence $\left(\mathrm{R}^{2}<0.10\right.$ for all tests). Over $95 \%$ of the $\mathrm{R}^{2}$ values from all linear and logistic

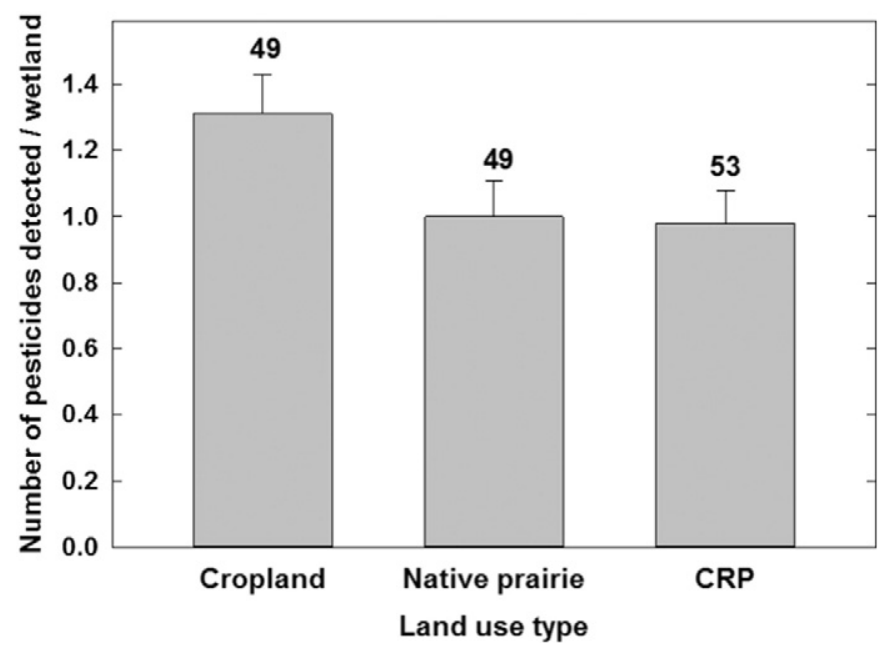

Fig. 2. Mean ( + SE) number of pesticides detected (out of 7 pesticides detected at least once) in sediments collected from prairie pothole wetlands in North and South Dakota in 2011. Wetlands were distributed among the three dominant land use types: active cropland, native prairie, and Conservation Reserve Program (CRP) land. Values above bars denote number of samples ( $\mathrm{n}$ ). regressions fell below 0.05 , suggesting the individual landscape factors we measured are unreliable for predicting either pesticide concentrations or detection.

\section{Discussion}

Our results reflect a single sampling event, and multiple samples over the course of the growing season could have produced different results. Nonetheless, our sampling of 151 wetlands across multiple land use types should provide a robust pesticide signature (Belden et al., 2012). Of the 18 pesticides examined, seven herbicides and fungicides were detected at least once. No insecticides were detected. Major field crops in the region are planted in May or Early June (http://www.rma. usda.gov/fields/mt_rso/2015/final/). Thus, our sampling period would follow two to ten weeks after planting depending on crop and site. Environmental half-lives vary greatly among analytes and between environmental conditions; however, the majority of analytes would be expected to persist in the environmental long enough for detection if

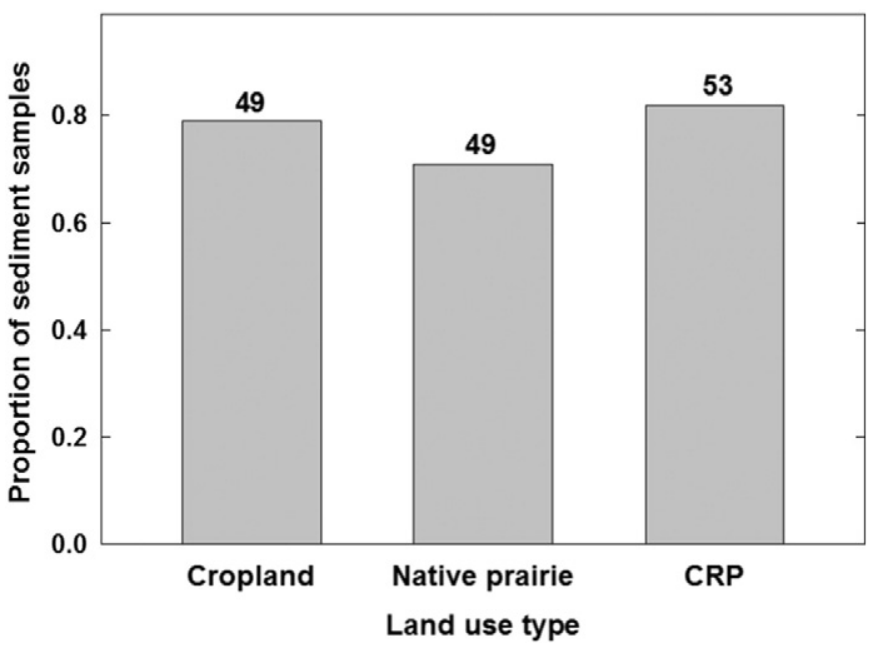

Fig. 3. Proportion of sediment samples from prairie pothole wetlands in North and South Dakota in 2011 with at least one detected pesticide. A total of seven pesticides were detected at least once. Wetlands were distributed among the three dominant land use types: active cropland, native prairie, and Conservation Reserve Program (CRP) land. Values above bars denote number of samples (n). 


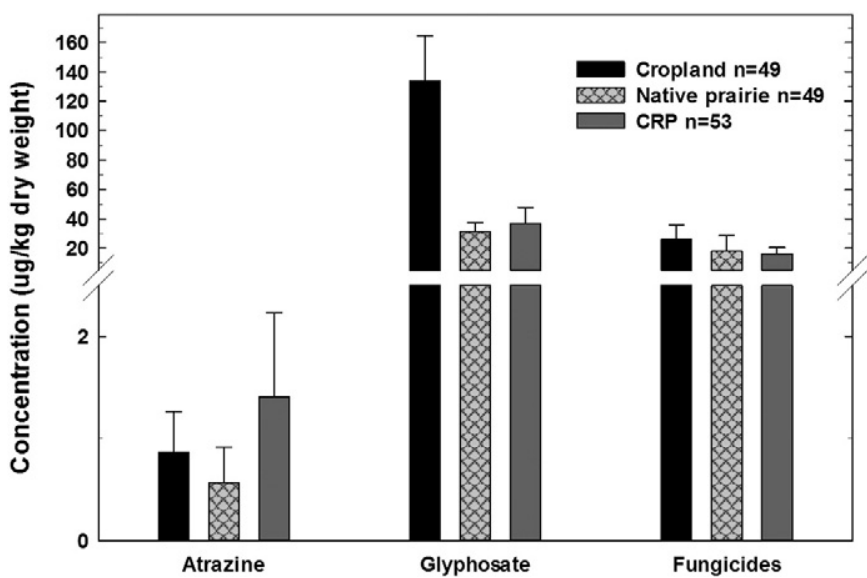

Fig. 4. Mean ( + SE) concentration of pesticides in sediments collected from prairie pothole wetlands in North and South Dakota in 2011. Non-detects were included in calculations. The five detected fungicides were pooled into one group for this analysis. Wetlands were distributed among the three dominant land use types: active cropland, native prairie, and Conservation Reserve Program (CRP) land.

a contamination event occurred just prior or just after planting. For example, atrazine, acetochlor, trifluralin, bifenthrin, chlorpyrifos, propiconazole, pyraclostrobin, cyfluthrin, and lambda cyhalothrin have soil half-lives expected to be greater than four weeks and frequently much longer (http://pmep.cce.cornell.edu/profiles/extoxnet/ index.html on 04/22/2016).

The pattern of "non-insecticide" pesticides being predominantly encountered in wetland sediments follows previous results in wetland sediments collected in other areas of the Great Plains (Belden et al., 2012). In the High Plains of western Nebraska, western Kansas, and eastern Colorado, insecticides were detected in 3\% of wetlands while $36 \%$ had herbicides. Similarly, in the Rainwater Basin of Nebraska, insecticides were found in $2 \%$ of wetlands while $64 \%$ had herbicides. The paucity of insecticide detections in wetland sediments could reflect the timing of sampling and applications. For example, the sampling period in the current study would likely miss applications of some pesticides such as fungicides and insecticides applied at the tassle stage in corn.

Also, insecticides are not used as much as other pesticides in some cases, as insect pest pressure is less uniform and less frequently encountered as other pests (e.g., weeds). USDA-NASS statistics show a range from 1 to $6 \%$ of corn, wheat, and barley receiving some type of insecticide treatment during 2010-2012 in North and South Dakota. Soybeans were the most heavily treated, with $10 \%$ and $17 \%$ of the 2012 crop treated with insecticide in North Dakota and South Dakota, respectively. Although incomplete for all combinations of crop type, location, and year, taken together these data show a low frequency of insecticide usage across the major crop types in the region, especially as compared to herbicides (see below). Further, we looked for insecticides that were included in the USDA-NASS list, supporting the appropriateness of our analyte list. Most insecticides investigated in this study partition to sediment, have moderately long half-lives, and have been found in sediment in other studies (Hintzen et al., 2009; Kuivila et al., 2012; Weston et al., 2004), suggesting the likely detection of the target insecticides if they were present. These results are in contrast of some legacy insecticides. For example, lindane was detected in $73 \%$ of water samples collected between 1991 and 1996 in Prairie Potholes in Saskatchewan (Donald et al., 1999). Moreover the lack of insecticides is in contrast to some other landscapes. For example, insecticides are common in stream bed sediment from some urban regions, in several studies occurring in the majority of samples (Hintzen et al., 2009; Hladik and Kuivila, 2012) and were detected in 70\% of samples in the Central Valley agricultural region of California (Weston et al., 2004).

Glyphosate, pyraclostrobin, and atrazine were the most frequently detected of the seven compounds in wetland sediments. Glyphosate readily partitions to sediment in Prairie Potholes (Degenhardt et al., 2012), and we observed glyphosate in $61 \%$ of our wetlands and those observations closely followed use patterns. For example, in North Dakota, glyphosate was applied to $84 \%$ of wheat in 2009 , at least $86 \%$ of corn in 2010 , and $63 \%$ or more of soybeans in 2012 (USDA, http://www.nass. usda.gov/Statistics_by_Subject/Environmental). These are likely conservative values as data are provided for multiple glyphosate formulations, which if added together would approach $100 \%$ coverage. This pattern of use is likely typical throughout the Great Plains, although we cannot compare these results to Belden et al. (2012) who did not analyze for glyphosate. Nonetheless, glyphosate use is commonly used throughout the Plains states on a variety of crops (USDA, http://www. nass.usda.gov/Statistics_by_Subject/Environmental).

Atrazine was the other herbicide detected in this study, and despite significant corn production in North and South Dakota, atrazine was observed in $8 \%$ of all samples (maximum $10 \%$ ) in cropland wetlands. NASS data suggest higher use, with atrazine applied to an estimated $26 \%$ of the 2010 corn acres in North Dakota, and 38\% in South Dakota. However, unlike glyphosate, atrazine use is more restricted to certain crops, such as corn and sorghum, but not soybeans or wheat, which make up a significant portion of the crop in the study area. Similarly, Belden et al. (2012) found that atrazine occurrence was below $20 \%$ in Texas, Oklahoma and New Mexico playa wetlands where cotton was the predominant crop. However, that level increased to $43-47 \%$ in cropland playas sampled in Colorado, Kansas, and Nebraska where corn production is much more prevalent. Atrazine sorbs to sediment less than the other pesticides detected in this study and may have been primarily located in the water column.

Fungicides, pyraclostrobin in particular, were detected in 30 to $35 \%$ of potholes. Pyraclostrobin was used on various crops including soybeans, wheat, and barley in North and South Dakota during 2009 through 2012 (USDA, http://www.nass.usda.gov/Statistics_by_Subject/ Environmental). However, actual percent use data were not shown except for 2011 barley in North Dakota (19\%). Overall, fungicide use varied among crops, with no indication of use in 2010 corn in either state, to $51 \%$ of the 2012 wheat crop in North Dakota being treated with some type of fungicide (USDA, http://www.nass.usda.gov/Statistics_by_ Subject/Environmental). Thus, we see a general agreement between frequency of detection in wetland sediments, and use data across the landscape. From a larger perspective, Belden et al. (2012) rarely detected fungicides in playa wetlands, with detections in two wetlands among 264 samples over six states. However, differences between studies could be driven by differences in predominant crop types and sampling years, more so for fungicides than other pesticides, as fungicide use has increased by about 250 to $350 \%$ over the past decade (USDA, http:// www.nass.usda.gov/Statistics_by_Subject/Environmental). Our results are similar for those found in streams in the southern and central United States where 20 of 29 streams had measureable concentrations of fungicides in water samples (Battaglin et al., 2011). Moreover, pyraclostrobin was detected in all stream bed sediment samples $(\mathrm{n}=20)$ using targeted collection near potato fields (Smalling et al., 2013).

\subsection{Toxicological significance of sediment residues}

Wetlands in heavily cropped watersheds are suspected to contain pesticides. Our data, and those of others (Belden et al., 2012) show that for sediments, pesticide contamination is mostly herbicides and fungicides, with few insecticides. These results are likely driven in part by the matrix, as water residues may show a different pattern, especially throughout the growing season (Anderson et al., 2013). Nonetheless, sediments are a source for pesticide exposure. Glyphosate was the pesticide of greatest concentration in cropland wetlands, with a median concentration above the QL of $90 \mu \mathrm{g} / \mathrm{kg}$. The toxicological relevance of the glyphosate concentrations we observed is difficult to assess. Toxicity of glyphosate itself is likely restricted to plants and possibly microbial communities, although results for the latter are conflicting and may 
reflect experimental design differences (Busse et al., 2001). For plants, time since initial exposure factors into the potential for toxicity, as glyphosate binds to soil and becomes less active (Tesfamariam et al., 2009). However, glyphosate formulations that include surfactants have significant toxicity to aquatic organisms, which is typically assessed in a water exposure (Giesy et al., 2000). Sediment studies show median lethal concentration (LC50) values for Ceriodaphnia dubia to be 244 and $340 \mathrm{mg} / \mathrm{kg}$ of glyphosate in spiked sediment at $0 \%$ total organic carbon (Tsui and Chu, 2004), values well above our maximum sediment concentration. Atrazine was detected with low frequency, but the observed concentrations were often twice or more above the EC25 for Lactuca sativa 21 day development ( $3.5 \mu \mathrm{g} / \mathrm{kg}$; EPA Ecotox Database). The ubiquitous nature of glyphosate and the exceedance of toxic concentrations by atrazine suggest that non-target plants could be affected, yet plants not of agricultural concern are rarely evaluated and extrapolation from laboratory to field conditions can be problematic (Clark et al., 2004).

Use of fungicides has increased use over the past several years and their toxicity has been evaluated in aquatic and terrestrial systems (Belden et al., 2010; Morrison et al., 2013; Peterson et al., 1994). However, it is difficult to compare our results to other studies due to different application methods (e.g., in water vs. sediment) and extrapolating between media. Pyraclostrobin was the most frequently observed fungicide in our samples and it has been shown toxic to invertebrates and vertebrates following simulated overspray events (Belden et al., 2010; Hooser et al., 2012; Morrison et al., 2013). However, pyraclostrobin readily binds to sediments and when applied directly to sediment $24 \mathrm{~h}$ prior to inundation or allowed to age on sediment for several days prior to exposure, invertebrate toxicity was absent or greatly minimized (Morrison et al., 2013; Ding et al., 2011). Further, the sediment concentration of pyraclostrobin after the sediment exposure was $2100 \mu \mathrm{g} / \mathrm{kg}, 5$-fold greater than the highest concentration in this study. We cannot determine whether pyraclostrobin is entering wetlands before or after binding to sediment, but it was detected with equal frequency across land use types, suggesting various routes of movement through the system.

\subsection{Land use differences and conservation impacts}

We hypothesized that land use would affect pesticide concentrations in wetlands, with native prairie and CRP being "protective" against pesticide input due to isolation from cropland and/or providing a buffer to potential runoff. Interestingly, glyphosate was present in over half the 102 non-crop wetlands, likely due to the widespread use, mobility, and spatial distribution of land use types (i.e., cropland in close proximity to native prairie wetlands). Indeed, atmospheric deposition contributes to pesticide transport and contamination to PPR wetlands and likely increases detection frequency (Messing et al., 2011). Nonetheless, glyphosate was detected less frequently and in lower concentrations in native prairie and CRP wetlands than those in cropland, demonstrating the ability of CRP to ameliorate pesticide contamination in these wetlands. Conversely, fungicides show little to no land use variation in either frequency of detection or concentration, perhaps due to similar factors listed for glyphosate, and differences in application methods (aerial vs. ground). Further, $30-40 \%$ overall detection of fungicides may not provide enough data to reliably examine a categorical effect, except in cases of a particularly strong signal (Helsel, 2005).

We know land use and upland management factors influence wetlands in various ways and that buffer zones protect wetlands from upland runoff (Castelle et al., 1994). Regardless, we were unable to demonstrate any relationship of consequence using either crop type, distance to crops, or watershed size. The spatial distribution and density of wetlands, heterogeneity of land use types, and pesticide use patterns, create a complex scenario that influences pesticide distribution. Density of wetlands and cultivation intensity in the PPR is high and despite the categorical classification of wetlands as cropland, native prairie, or CRP, the average ( \pm SE) distance from the center of our cropland wetlands to the nearest cornfield in 2011 was $149 \pm 31 \mathrm{~m}$ compared to 300 to $400 \mathrm{~m}$ for wetlands in native prairie and CRP. Similar trends were observed for cropland wetlands relative to soybean and wheat fields. Thus, although our land use classifications are supported by these data, they also indicate that even wetlands in native prairie are relatively close to cropland.

\section{Conclusions}

The goal of this study was to assess the influence of land use, in particular CRP, on pesticide levels in wetland sediments in the PPR, a heavily cultivated landscape with a high density of embedded wetlands. The density of wetlands and intensity of cropland activity in the region likely lead to pesticide input in non-agricultural wetlands, as observed for CRP and native prairie wetlands in this study. Further, this could have influenced our ability to identify any landscape level variables, other than the three land use categories, useful for explaining contaminant levels in sediments. Overall, we detected few pesticides in wetland sediments, but we recognize that our data represent a single point in time sampling event, that our pesticide list is not exhaustive, and that analyzing sediments alone may not account for all pesticide input. We were able to evaluate the ability of CRP to protect wetlands from glyphosate input, and it did provide significant amelioration for PPR wetlands. As a conservation program, CRP can improve ecosystem services such as biodiversity provisioning, water storage, carbon storage (Gleason et al., 2011) and pesticide amelioration.

\section{Acknowledgements}

We thank the Natural Resource Conservation Service - CEAP Wetlands (CD-966441-01) for their financial assistance.

\section{References}

Anderson, T.A., Salice, C.J., Erickson, R.A., McMurry, S.T., Cox, S.B., Smith, L.M., 2013. Effects of land use and precipitation on pesticides and water quality in playa lakes of the Southern High Plains. Chemosphere 92, 84-90.

Battaglin, W.A., Sandstrom, M.W., Kuivila, K.M., Kolpin, D.W., Meyer, M.T., 2011. Occurrence of azoxystrobin, propiconazole, and selected other fungicides in U.S. streams, 2005-2006. Water Air Soil Pollut. 218, 307-322.

Belden, J.B., McMurry, S.T., Smith, L.M., Reilley, P., 2010. Acute toxicity of fungicide formulations to amphibians at environmentally relevant concentrations. Environ. Toxicol. Chem. 29, 2477-2480.

Belden, J.B., Hanson, B., McMurry, S.T., Smith, L.M., Haukos, D.A., 2012. Assessment of the effects of farming and conservation programs on pesticide deposition in High Plains wetlands. Environ. Sci. Technol. 46, 3424-3432.

Busse, M.D., Ratcliff, A.W., Shestak, C.J., Powers, R.F., 2001. Glyphosate toxicity and the effects of long-term vegetation control on soil microbial communities. Soil Biol. Biochem. 33, 1777-1789.

Castelle, A.J., Johnson, A.W., Conolly, C., 1994. Wetland and stream buffer size requirements-a review. J. Environ. Qual. 23, 878-882.

Clark, J., Ortego, L.S., Fairbrother, A., 2004. Sources of variability in plant toxicity testing. Chemosphere 57, 1599-1612.

Cowardin, L.M., Carter, V., Golet, F.C., LaRoe, E.T., 1979. Classification of Wetlands and Deepwater Habitats of the United States. FWS/OBS-79/31, U.S. Fish and Wildlife Service, Washington, DC 103 pp.

Dahl, T.E., 2014. Status and Trends of Prairie Wetlands in the United States 1997 to 2009 U. S. Department of the Interior. Fish and Wildlife Service, Ecological Services, Washington, DC (67 pp).

Daniel, D.W., Smith, L.M., Haukos, D.A., Johnson, L.A., McMurry, S.T., 2014. Land use and conservation reserve program effects on the persistence of playa wetlands in the High Plains. Environ. Sci. Technol. 48, 4282-4288.

Degenhardt, D., Humphries, D., Cessna, A.J., Messing, P., Badiou, P.H., Raina, R., Farenhorst A., Pennock, D.J., 2012. Dissipation of glyphosate and aminomethylphosphonic acid in water and sediment of two Canadian prairie wetlands. J. Environ. Sci. Health B 47, 631-639.

Ding, Y., Weston, D.P., You, J., Rothert, A.K., Lydy, M.J., 2011. Toxicity of sediment-associated pesticides to Chironomus dilutes and Hyalella azteca. Arch. Environ. Contam. Toxicol. 61, 83-92.

Donald, D.B., Syringiannis, J., Hunter, F., Weiss, G., 1999. Agricutural pesticides threaten the ecological integrity of northern prairie wetlands. Sci. Total Environ. 231, 173-181.

Euliss, N.H., Smith, L.M., Liu, S., Duffy, W.G., Faulkner, S.P., Gleason, R.A., Eckles, S.D., 2011. Integrating estimates of ecosystem services from conservation programs and practices into models for decision makers. Ecol. Appl. 21, S128-S134. 
Giesy, J.P., Dobson, S., Solomon, K.R., 2000. Ecotoxicological risk assessment for Roundup herbicide. Rev. Environ. Contam. Toxicol. 167, 35-120.

Gilliom, R.J., 2007. Pesticides in US streams and groundwater. Environ. Sci. Technol. 41 $3408-3414$.

Gleason, R.A., Tangen, B.A., 2008. Chapter D: floodwater storage. In: Gleason, R.A Laubhan, M.K., Euliss, N.H. (Eds.), In Ecosystem Services Derived From Wetland Conservation Practices in the United States Prairie Pothole Region With Emphasis on the U.S. Department of Agriculture Conservation Reserve and Wetlands Reserve Programs. U.S. Geological Professional Paper 1745, p. 58.

Gleason, R.A., Euliss Jr., N.H., Tangen, B.A., Laubhan, M.K., Browne, B.A., 2011. USDA conservation program and practice effects on wetland ecosystem services in the Prairie Pothole Region. Ecol. Appl. 21, S65-S81.

Helsel, D.R., 2005. More than obvious: better methods for interpreting nondetect data. Environ. Sci. Technol. 39, 419-423A.

Hintzen, E.P., Lydy, M.J., Belden, J.B., 2009. Occurrence and potential toxicity of pyrethroids and other insecticides in bed sediments of urban streams in central Texas. Environ. Pollut. 157, 110-116.

Hladik, M.L., Kuivila, K.M., 2012. Pyrethroid insecticides in bed sediments from urban and agricultural streams across the United States. J. Environ. Monit. 14, 1838-1845.

Hooser, E.A., Belden, J.B., Smith, L.M., McMurry, S.T., 2012. Acute toxicity of three strobilurin fungicide formulations and their active ingredients to tadpoles. Ecotoxicology $21,1458-1464$

Johnston, C.A., 2013. Wetland losses due to row crop expansion in the Dakota Prairie Pothole Region. Wetlands 33, 175-182.

Kuivila, K.M., Hladik, M.L., Ingersoll, C.G., Kemble, N.E., Moran, P.W., Calhoun, D.L., Nowell, L.H., Gilliom, R.J., 2012. Occurrence and potential sources of pyrethroid insecticides in stream sediments from seven U.S. metropolitan areas. Environ. Sci. Technol. 46, 4297-4303.

Messing, P.G., Farenhorst, A., Waite, D.T., McQueen, D.A.R., Sproull, J.F., Humphries, D.A. Thompson, L.L., 2011. Predicting wetland contamination from atmospheric deposition measurements of pesticides in the Canadian Prairie Pothole region. Atmos. Sci. $45,7227-7234$

Morrison, S.A., McMurry, S.T., Smith, L.M., Belden, J.B., 2013. Acute toxicity of pyraclostrobin and trifloxystrobin to Hyalella azteca. Environ. Toxicol. Chem. 32, 1516-1525.

Peterson, H.G., Boutin, C., Martin, P.A., Freemark, K.E., Ruecker, N.J., Moody, M.J., 1994 Aquatic phyto-toxicity of 23 pesticides applied at expected environmental concentrations. Aquat. Toxicol. 28, 275-292.
Samson, F., Knopf, F., 1994. Prairie conservation in North America. Bioscience 44, 418-421.

Shelton, L.R., Capel, P.D., 1995. Guidelines for collecting and processing samples of stream bed sediment for analysis of trace elements and organic contaminants for the National water-quality assessment program. US Geological Survey Report, pp. 94-458

Smalling, K.L., Reilly, T.J., Sandstrom, M.W., Kuivila, K.M., 2013. Occurrence and persistence of fungicides in bed sediments and suspended solids from three targeted use areas in the United States. Sci. Total Environ. 447, 179-185.

Smith, L.M., 2003. Playas of the Great Plains. University of Texas Press, Austin, TX, USA.

Smith, L.M., Euliss Jr., N.E., Wilcox, D., Brinson, M., 2008. Application of a geomorphic and temporal perspective to wetland management in North America. Wetlands 28, 563-577.

Smith, L.M., Haukos, D.A., McMurry, S.T., LaGrange, T., Willis, D., 2011. Ecosystem services provided by playas in the High Plains: potential influences of USDA conservation programs. Ecol. Appl. 21, S82-S92.

Stubbs, M., 2013. Conservation Reserve Program (CRP): Status and Issues; Congressional Research Service Report for Congress, NO. R42783, March 18.

Sullivan, P., Hellerstein, D., Hansen, L., Johansson, R., Koenig, S., Lubowski, R., Mcbride, W., McGranahan, D., Roberts, M., Vogel, S., Bucholtz, S., 2004. The Conservation Reserve Program: Economic Implications for Rural America; Agricultural Economic Report 834. Economic Research Service, Washington, DC.

Tesfamariam, T., Bott, S., Cakmak, I., Romheld, V., Neumann, G., 2009. Glyphosate in the rhizosphere-role of waiting times and different glyphosate binding forms in soils for phytotoxicity to non-target plants. Eur. J. Agron. 31, 126-132.

Tsui, M.T.K., Chu, L.M., 2004. Comparative toxicity of glyphosate-based herbicides: aqueous and sediment porewater exposures. Arch. Environ. Contam. Toxicol. 46, 316-323.

USDA, United States Department of Agriculture, Farm Service Agency, 2013e. The Conservation Reserve Program: 39th Signup Results. http://www.fsa.usda.gov/Internet/ FSA_File/su45state0913.pdf.

Weston, D.P., You, J., Lydy, M.J., 2004. Distribution and toxicity of sediment-associated pesticides in agriculture-dominated water bodies of California's Central Valley. Environ. Sci. Technol. 38, 2752-2759.

Wu, J., Weber, B., 2012. Implications of a Reduced Conservation Reserve Program. The Council on Food, Agriculture \& Resource Economics http://issuu.com/cfare/docs/implicationsofareducedconservationreserveprogram. (Accessed on December 16, 2014). 